Oklahoma Native Plant Record

Volume 7, Number 1, December 2007

\title{
Editorial
}

\section{Botanizing with Larry Magrath}

Sunday, October 4, 1998. A field trip for two doesn't take much planning - a phone call will do: "One of my students has brought in a collection of Scirpus hallii. Want to go with me on Sunday to verify the site?" Well, of course! Larry was one of the state's most ardent collectors, and S. hallii (name since changed to Schoenoplectus hallii) is a sedge. That makes it a plant I need to know.

Just after 8 a.m. that Sunday I picked up Larry and his gear in Chickasha, and we headed southwest. But first - he'd thought of another lake that was "almost on the way", and there were exposed mud flats just covered with sedges. So we went due west for maybe 10 miles, to Lake Burtschi. There were thousands of inch-tall sedges of several different species; Cyperus surinamensis, C. aristatus, Fimbristylis autumnalis, and Fuirena simplex, mostly. They lay on the damp sand like a city lawn; tiny annual species doing their best to set seed before frost. There we also collected samples of Arundo donax, a grass that grows in shallow water, and can reach more than two meters tall.

Then, "since we are in the neighborhood" we stopped at a private property called Williams' Wilderness, whose owner had given permission. There we found an orchid, Hexalectris spicata and some other goodies.

Traveling SW on SH19, we stopped along the south edge of Apache near Lakeside Village to see how Lake Ellsworth had fared. That lake was down ten feet, and had exposed acres of sandy bottom, much of it covered with the tiny annual sedges. All were in furious bloom. There we collected a sedge-like grass, Eragrostis reptans; as well as Fimbristylis vablii, Cyperus odoratus, Amannia coccinea, and a strange liverwort called Riccocarpus natans. The upper edges were banked with a vigorous morning glory with small white flowers, Ipomoea lacunosa.

Finally we reached Jed Johnson Lake in the Wichita Mountain Wildlife Reservation. There, an expanse of mud flats some 4 meters wide and ten meters long had been exposed by the low water. The shoreline was composed of broken red-granite gravels and sand, much disturbed by fishermen. Scirpus ballii was there in abundance and in bloom or fruit. Larry counted 114 plants, and each of us collected a specimen for our herbarium.

Our trip had been both entertaining and successful. Think it was over? You've never been on a field trip with Larry! We were free to wander as far and wide as our strength and the day lasted. We checked Rush Lake, also on the Reserve, and found it embedded in a huge stand of Eleocharis quadrangulata. While I took pictures, a curious armadillo came right up and sniffed near-sightedly at my shoe.

Lunch with Larry was always a challenge: it had to be fast, and it had to be vegetarian. Veggie fast food isn't readily available along country roads. We settled for sub sandwiches at the Love's Station on SH49. Dodging traffic through Lawton, we took SH 7 east to SH 65, then went south through Temple, turned east there on $\mathrm{SH} 5$, and soon arrived at Moneke Park near Lake Waurika. Hiking through an open forest community, we found the other relative of poke-weed, Rivina humilis, and in bloom. First time I'd ever seen that. It was a real treat.

Our day was coming to an end. The cloud bank that had hovered to the west all day long grew higher and darker. We reluctantly headed north on US 81 , but soon 
had to make a stop just north of Addington. There, beside the highway, is a large prairiedog community, and we enjoyed their company until it grew too dark for photography. By the time we reached Chickasha, it was pitch-black except for the lightning that was almost intense enough to drive by. Larry unloaded his prizes in a heavy downpour, and I headed for home by SH9. Again, lightning and heavy, heavy rain accompanied the trip.

By way of the evening news, I learned that Ninnekah, just south of Chickasha, had been struck by a tornado right after we drove through, and that a swarm of them had produced the lightning that made the passage so interesting. The tornadoes had covered a large swath of central Oklahoma that night while Larry and I were busy pressing the plants and writing up our notes.

Over the years there were many such field trips with Larry, most of them with the Oklahoma Native Plant Society or The Nature Conservancy. Each of them was "floriferous" and interesting. The photo below is from one of our trips to Round Mountain in LeFlore County with Jim Norman and Charles Lewallen, who set up the remote photo.

Patricia Folley, 1 June 2007

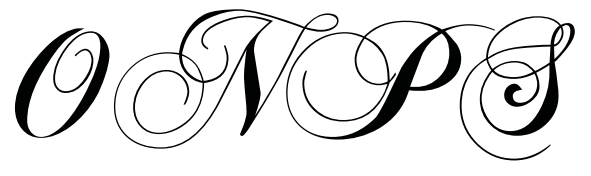

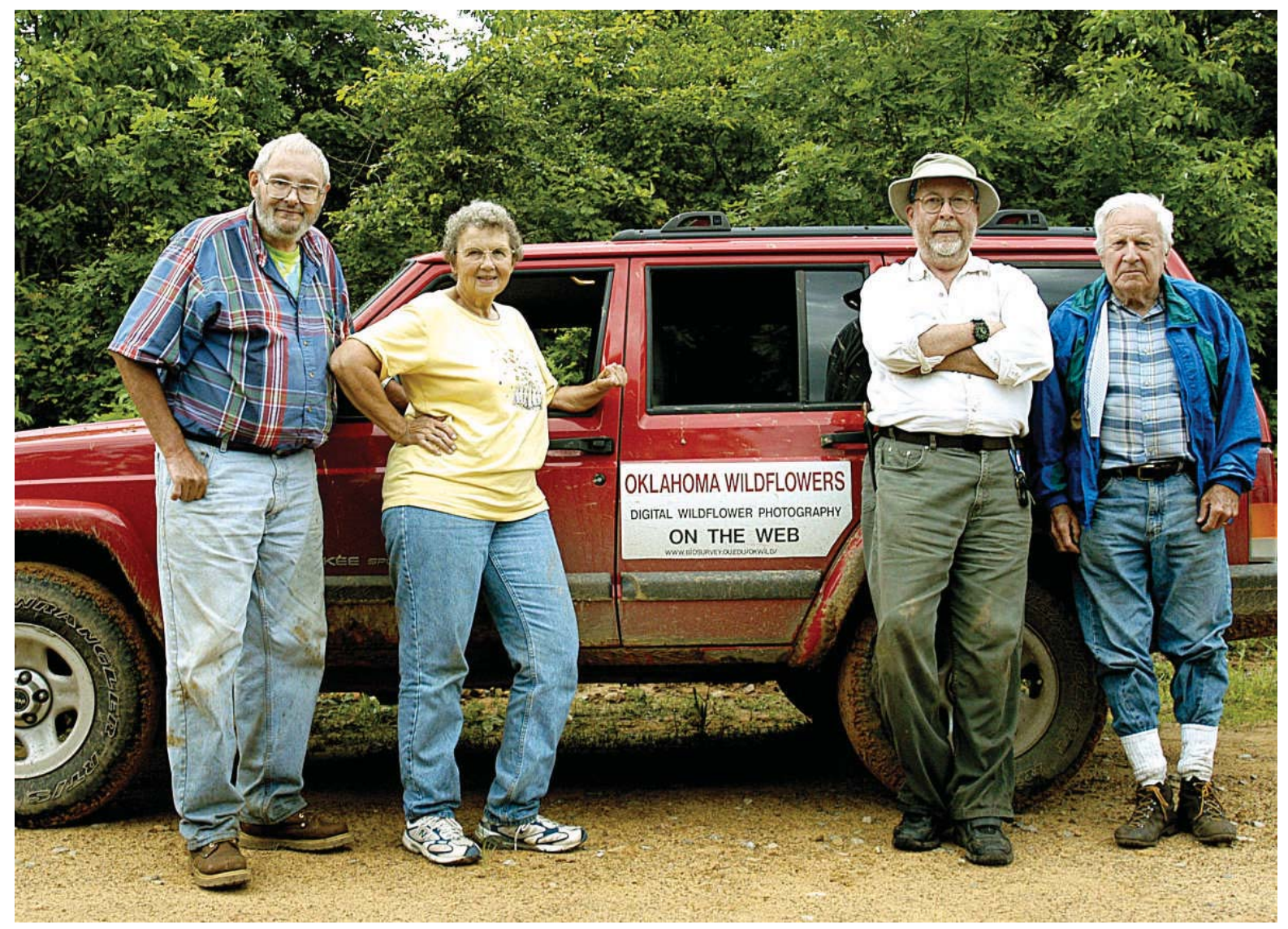

Larry Magrath, botanizing with Patricia Folley, Charles Lewallen, and Jim Norman. 